\title{
POST-FIRE ABUNDANCE AND AGE COMPOSITION DYNAMICS OF LACERTA AGILIS (REPTILIA, LACERTIDAE) IN THE ORENBURG STATE NATURE RESERVE (RUSSIA)
}

\author{
Andrey G. Bakiev*, Roman A. Gorelov, Anastasia A. Klenina \\ Institute of Ecology of the Volga River Basin of RAS, Russia \\ *e-mail: herpetology@list.ru
}

Received: 31.12.2018. Revised: 02.04.2019. Accepted: 07.06.2019.

\begin{abstract}
In different months during 2015-2017, the abundance and sex-age structure of the Sand lizard (Lacerta agilis) were studied on two transects. Parallel transects were established in the southeastern part of the cluster area «Burtinskaya steppe» of the Orenburg State Nature Reserve (Russia). The length of each transect was $3 \mathrm{~km}$. The width of the mineralised plowed strip between the transects was 9-11 m. Transect 2 was located in the area burnt in August 2014, while transect 1 was situated in the area burnt in August 2016. In terms of size and external morphological traits, the captured Sand lizards were divided into three groups: juvenile individuals, adult males, and adult females. After measurements, the marked animals were put back to the places of capture. The number and sex-age structure were restored on transects in May - June, after the first winter following the fire impact. We found that on transect 1, the species abundance at late April - early May 2015 was almost three times higher (18.67 individuals / km) than on transect 2 (6.67 individuals / km). However, at late May 2015, the species abundance on both transects became almost the same (12.67 individuals / $\mathrm{km}$ in transect 1 against 11.33 individuals $/ \mathrm{km}$ in transect 2). The juvenile individuals suffered from the fire influence more than adults. After the 2016 fire (i.e., in mid-May 2017), the proportion of one-year-old individuals was $21.2 \%$ of the total number of Sand lizards recorded in transect 1, while it counted $67.3 \%$ of the total number of Sand lizards recorded in transect 2, burnt in 2014. We believe that the rapid recovery of the abundance and sex-age structure in the Burtinskaya steppe was associated with the migration of Sand lizards through the mineralised strip separating the burnt and non-burnt transects.
\end{abstract}

Key words: cluster area «Burtinskaya steppe», fire, Orenburg region, Sand lizard

\section{Introduction}

The Protected Areas in which special post-fire restoration measures are not carried out provide an opportunity to study the natural mechanisms for the restoration of ecosystems and their individual components. Reptiles are important components of ecosystems. The post-fire restoration of populations of these animals in Protected Areas has not been studied enough yet (Langford et al., 2007; Lebedinskii, 2017; Lebedinskii \& Pestov, 2017).

Wildfires have a variety of effects on reptiles, including direct injuries and mortality, as well as indirect effects on the animals through changes in the available environment resources (Andersen et al., 2005; Hromada et al., 2018). During fires, reptiles hide under ground objects, climb trees, in burrows, or leave the burning areas (Russell et al., 1999; Smith et al., 2012).

The pyrogenic damage degree in the steppe largely depends on the strength and direction of the wind at the ignition time. According to data obtained in the Black Sea Biosphere Reserve (Ukraine), the top soil layer remains intact under conditions of a strong wind. And reptiles can rather successfully wait till the end of a fire in rodent holes. Under a weak wind, the top soil layer burns out more strongly, especially in small depressions with a large volume of dead grass matter. In such places, reptiles hidden in small mammal burrows are dying. Reptiles of the semi-aquatic faunistic complex die in burnt reed grass (Phragmites australis (Cav.) Trin. ex Steud.) communities. However, the post-fire restoration of reed grass beds occurs rapidly. Semi-aquatic reptiles inhabit these plant communities for 2-3 months. The rate and success of post-fire restoration depends not only on the area of the fire-affected site, but also on the weather conditions under which the fire occurs, the season and the phenological period. In various natural complexes, pyrogenic successions have various rates. For example, the reed grass 
beds have the highest restoration rate. Steppe sites have a lower rate of post-fire restoration. An increased abundance of snakes feeding on dead large insects has been noted on recently burnt areas (Selyunina, 2008).

During fire influence, the death of the Smooth Snake Coronella austriaca Laurenti, 1768, the Steppe Viper Vipera renardi (Christoph, 1861), the Dice Snake Natrix tessellata (Laurenti, 1768) was recorded in the Nature Reserve «Khomutovskaya steppe »(Ukraine). After the 2002 fire, Coronella austriaca did not occur anymore on the coastal slope above the manor of the Nature Reserve «Khomutovskaya steppe». The April 2003 fire negatively influenced Natrix tessellata, appearing after wintering. At the site damaged by fire in March 2007, dead specimens of Coronella austriaca and Vipera renardi were found (Timoshenkov \& Timoshenkova, 2007). The data on the 2014 abundance of Zootoca vivipara (Lichtenstein, 1823 ) on the burnt and unburnt sites have already been published (Eplanova et al., 2018).

In this paper, we aimed to study the abundance and sex-age structure of the Sand lizard (Lacerta agilis Linnaeus, 1758).

\section{Material and Methods}

In 2015-2017, we established two tape transects (numbers 1 and 2) along the southeastern border of the cluster area «Burtinskaya steppe» (Fig.). Each of them was $3 \mathrm{~km}$ in length and $5 \mathrm{~km}$ in width. Before the creation of the Orenburg State
Nature Reserve (in 1989), this area was plowed up, despite the soil unsuitability due to the large amount of rubble and the low thickness of the humus horizon (Kalmykova, 2017). There was a mineralised plowed tape of 9-11 m wide passed between transect 1 and transect 2 . Such an arrangement of both transects situated in similar steppe conditions allowed us to make it possible to obtain correct data for a comparative analysis of the abundance and other parameters of reptiles. Transect 1 was located through the area burnt in August 2016, while transect 2 was established through the area burnt in August 2014.

Sand lizards were caught at transects in 2015 (29 April - 05 May, 24-31 May, and 2224 August), in 2016 (05-08 May, 09-13 June, and 02-05 August), in 2017 (12-15 May, 14-16 June, and 20-22 July). During data collection, catchers simultaneously moved along both transects separated by the mineralised strip. Sand lizards found at transects were caught for marking, measuring and weighing. After measurements, all animals were put back at the places where they were caught. We marked specimens to avoid re-capture of lizards within the study period. In terms of size and body weight, lizards were divided into one-year-old individuals and adults. At both transects, we did not meet lizards born in the year of capture. We determined the sex of adult lizards on the basis of external morphological traits (body colour, tail shape, dimensions of femoral pores).

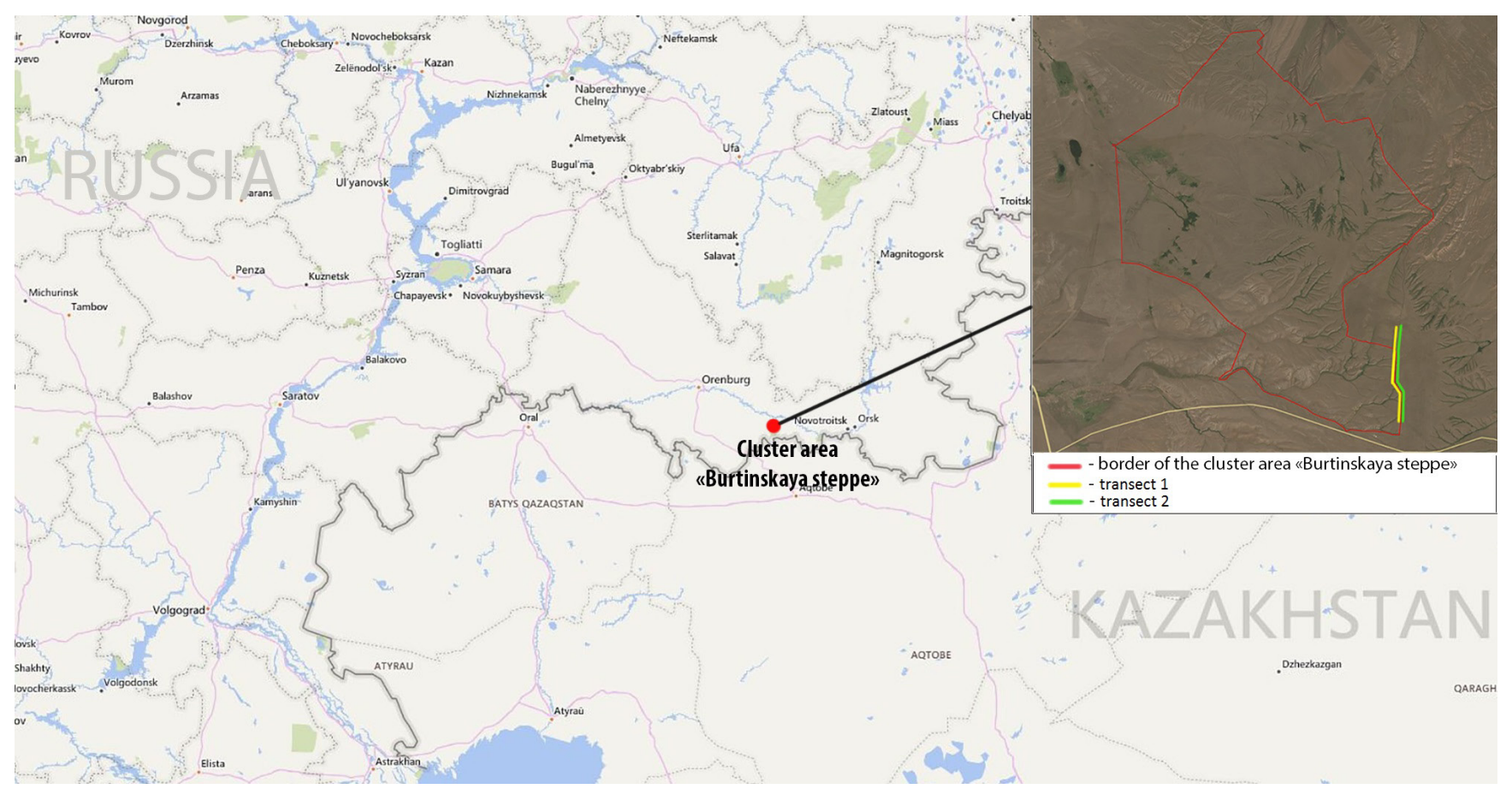

Fig. Geographic location of the study area, transect 1 and transect 2. 
To monitor the herpetofauna status in the cluster area «Burtinskaya steppe» of the Orenburg State Nature Reserve (Russia) influenced by fire, we used various parameters: abundance, age-sex structure, body condition index, predation press (Bakiev et al., 2017).

\section{Results and Discussion}

Table 1 presents data on the Lacerta agilis abundance at both established transects of the cluster area «Burtinskaya steppe» studied in 20152017. In 2015-2016, 264 lizards were counted, including 154 individuals on transect 1 (burnt in 2016) and 110 individuals on transect 2 (burnt in 2014). In 2017, 226 lizards were counted. Of them, 94 individuals were found on transect 1 and 132 individuals were recorded on transect 2.

Late April - early May 2015, the Sand lizard abundance (56 individuals or 18.67 individuals $/ \mathrm{km}$ ) was almost three times higher at transect 1 , than at transect 2 (20 individuals or 6.67 individuals / $\mathrm{km}$ ). Therefore, the 2014 fire severely decreased the abundance of Sand lizards in the burnt area. However, at late May 2015, the species abundance became almost the same on both transects. This year, the abundance of Sand lizards at transect 1 decreased, while it increased at transect 2 . We believe, the only possible reason for such dynamics was the May 2015 migration of Sand lizards mainly from the unburnt area (transect 1) to the burnt area (transect 2) across the mineralised strip. Apparently, we found an opposite situation during the fire influence and immediately after fire damage, when the survived lizards migrated from the burnt areas to unburnt sites. It was caused by the lack of vegetation cover, which protects reptiles from predators and provides food supply. Probably, the late May return migration of lizards was caused both by the vegetation restoration at the burnt areas and by the increase competition for food resources at the unburnt areas due to the higher density of the Sand lizards population over there. The sharp decrease in the species abundance on both transects late August 2015 can be explained by the leaving of lizards for wintering.

Late May 2015 - early August 2016, the species abundance on both transects had similar dynamics. Late August 2015 and early May 2016, the species abundance was equal on the two transects. So, if you combine two samples $\left(\mathrm{n}_{1}+\mathrm{n}_{2}\right)$, then the proportion of each samples within each transect would be 0.50 . For instance, the late August 2015 species abundance on both burnt and unburnt transects was 1.33 individuals / km. Similarly, it reached 8.67 individuals / km equally at both transects early May 2016.

In 2017, the species abundance at transect 1 (burnt in 2016) was 1.2-1.6 times lower than at transect 2, which has already recovered after the 2014 fire and thus was treated as unburnt site. In most cases, the proportion of samplings on transects differs from 0.50. By comparing the differences in the proportion of lizard abundance with the general proportion of 0.50 , we revealed statistically significant differences only for late April - early May 2015 (p < 0.01 ). In other cases, the null hypothesis cannot be rejected even at the 5\% significance level.

After the 2014 fire, the proportion of lizard abundance at the transects did not differ statistically significantly from the $0.50(p>0.05)$ starting since late May 2015. For a short period of time (May 2015 ) the proportion of lizard abundance ceased to differ significantly from $50 \%$ at transect 1 burnt in 2014. The fact of levelling of differences in May 2015 for the next year after the 2014 fire was confirmed by 2017 data, when after the 2016 fire, the species abundance on transect 1 was 1.6 times lower than on transect 2 in mid-May 2017, but it did not differ significantly $(\alpha=0.05)$ from $50 \%$.

Table 1. The abundance of Lacerta agilis on the studied transects in 2015-2017

\begin{tabular}{|c|c|c|c|c|c|}
\hline \multirow{2}{*}{ Date } & \multirow{2}{*}{ Total number of specimens $(n)$} & \multicolumn{2}{|l|}{ Transect 1} & \multicolumn{2}{|l|}{ Transect 2} \\
\hline & & Total number of specimens $\left(n_{1}\right)$ & $n_{1} / \mathrm{km}$ & Total number of specimens $\left(n_{2}\right)$ & $n_{2} / \mathrm{km}$ \\
\hline \multicolumn{6}{|c|}{ After the fire impact (August 2014) } \\
\hline Late April - early May 2015 & 76 & 56 & 18.67 & 20 & 6.67 \\
\hline Late May 2015 & 72 & 38 & 12.67 & 34 & 11.33 \\
\hline Late August 2015 & 8 & 4 & 1.33 & 4 & 1.33 \\
\hline Early May 2016 & 52 & 26 & 8.67 & 26 & 8.67 \\
\hline Mid-June 2016 & 30 & 14 & 4.67 & 16 & 5.33 \\
\hline Early August 2016 & 26 & 16 & 5.33 & 10 & 3.33 \\
\hline \multicolumn{6}{|c|}{ After the fire impact (August 2016) } \\
\hline Mid-May 2017 & 85 & 33 & 11.00 & 52 & 17.33 \\
\hline Mid-June 2017 & 65 & 27 & 9.00 & 38 & 12.67 \\
\hline Mid-July 2017 & 76 & 34 & 11.33 & 42 & 14.00 \\
\hline
\end{tabular}


Consequently, in the periphery of areas burnt late summer, the Lacerta agilis abundance was restoring after the first wintering following the summer fire. Perhaps, the observed decrease in the species abundance was associated not only with the animal death during the fire, but also with the fireinfluenced deterioration of their wintering conditions. As a result of the fire impact, grass and shrub vegetation, which plays a layering role between snow cover and soil during winter, has practically disappeared. Kalmykova \& Soroka (2017) noted a significant decrease in temperature below the soil surface (at a depth of $30 \mathrm{~cm}$ ), a presence of sharp temperature fluctuations, and a decrease in humidity during the winter period in the burnt areas in comparison to unburnt sites.

The sex-age structure of Lacerta agilis populations shows abundance proportions of yearlings (juveniles), adult males (adults $\widehat{\partial}$ ) and adult females (adults $Q$ 오) of the Sand lizard found in both transects, presented in Table 2.

Late April - early May 2015, the percentage of juveniles and female adults of Lacerta agilis at transect 1 was higher than at transect 2. However, these differences were not statistically significant $(p>0.05)$. Late May 2015, the sex-age structure at both transects evened out even more. Late August 2015, the abundance of male adults, female adults and juveniles became the same at the burnt and unburnt areas. And we found no statistically significant differences between both transects during following observations. On the contrary, midMay and mid-June 2017, transect 1 differed from transect 2 by a lower abundance of juveniles. Differences in sample proportions were highly significant $(\mathrm{p}<0.01)$. Probably, the juvenile individuals of Lacerta agilis died first as a result of steppe fires.

\section{Conclusions}

As a result of fires in 2014 and 2016, which influenced the cluster area «Burtinskaya Steppe» of the Orenburg State Nature Reserve, the Lacerta agilis abundance decreased at areas adjacent to the fire border. It especially concerned juvenile individuals. After the first wintering after the fire impact, we noted the restoration of the abundance and sex-age structure of the Sand lizard population at the periphery of the steppe areas burnt late summer. The restoration we studied in the cluster area «Burtinskaya Steppe» was associated with the Sand lizard migration through a mineralised strip dividing the burnt and unburnt sites. The changes in abundance and sex-age structure of this species were more remarkable under fire influence in comparison to the body condition index and the predation press.

\section{Acknowledgments}

The authors are grateful to O.G. Kalmykova, M.A. Khramova, O.I. Zinenko and M.K. Ryzhov for their help in field research and the text translation into English.

Table 2. Sex-age structure of the Lacerta agilis populations at both transects

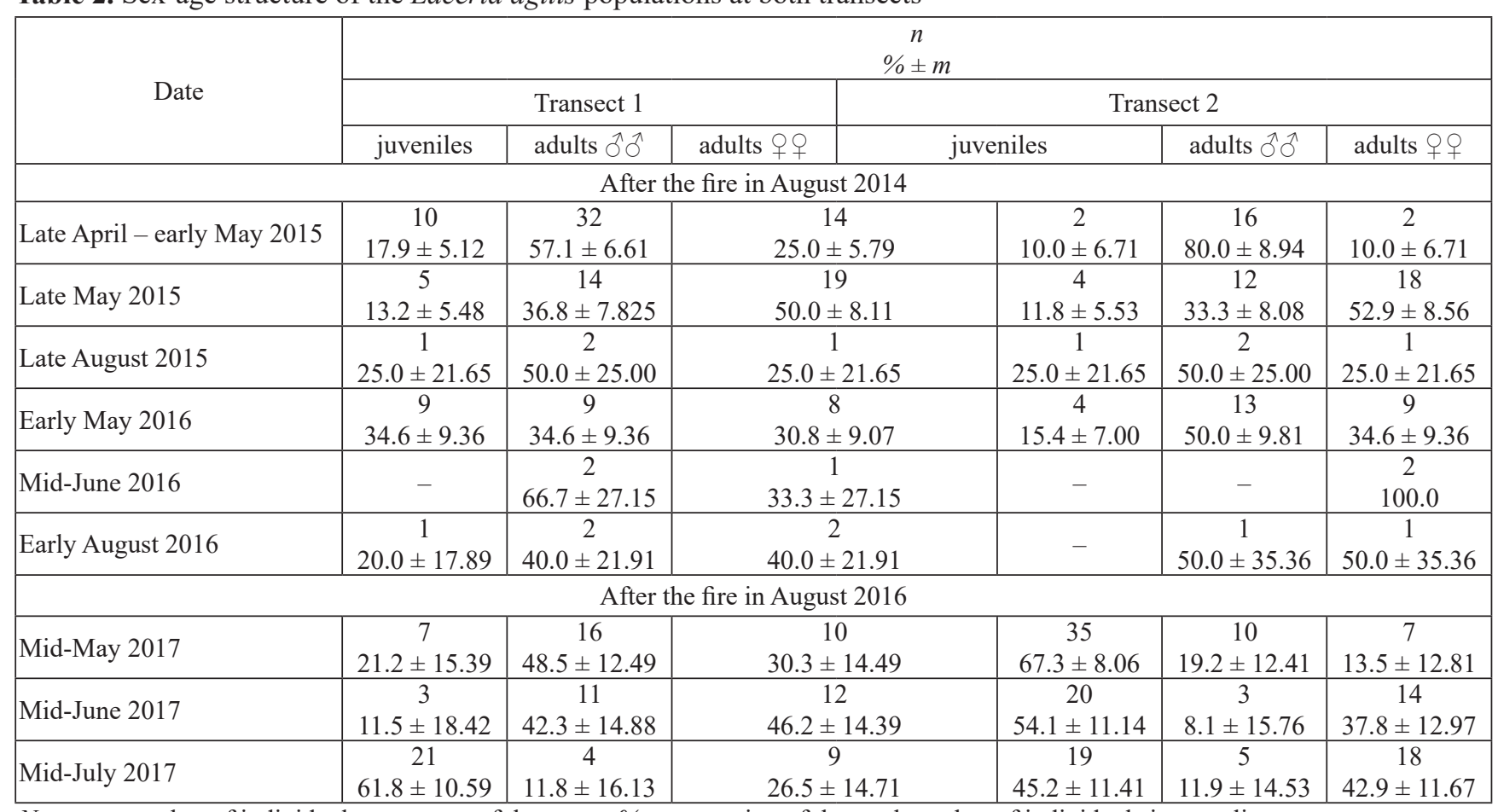

Note: $n$ - number of individuals; $m$ - error of the mean; $\%$ - proportion of the total number of individuals in sampling. 


\section{References}

Andersen A.N., Cook G.D., Corbett L.K., Douglas M.M., Eager R.W., Russell-Smith J., Setterfield S.A., Williams R.J., Woinarsky J.C.Z. 2005. Fire frequency and biodiversity conservation in Australian tropical savannas: Implications from the Kapalga fire experiment. Austral Ecology 30(2): 155-167. DOI: 10.1111/j.1442-9993.2005.01441.x

Bakiev A.G., Klenina A.A., Gorelov R.A., Khramova M.A. 2017. Herpetofauna monitoring. In: Experience of organising monitoring studies of post-fire changes in steppe ecosystems: approaches and methods. Orenburg: South Ural. P. 75-81. [In Russian]

Eplanova G.V., Kalmykova O.G., Bakiev A.G., Klenina A.A. 2018. Ecology and some morphological characteristics of the Zootoca vivipara (Reptilia: Lacertidae) on the southern periphery of its range in the steppe zone (Orenburg State Nature Reserve, Russia). Nature Conservation Research 3(Suppl.1): 98-109. DOI: 10.24189/ ncr.2018.058 [In Russian]

Hromada S.J., Howey H.A.F., Dickinson M.B., Perry R.W., Roosenburg W.M., Gienger C.M. 2018. Response of reptile and amphibian communities to the reintroduction of fire in an oak/hickory forest. Forest Ecology and Management 428: 1-13. DOI: 10.1016/j.foreco.2018.06.018

Kalmykova O.G. 2017. Brief description of the model area. In: Experience of organising monitoring studies of post-fire changes in steppe ecosystems: approaches and methods. Orenburg: South Ural. P. 10-14. [In Russian]

Kalmykova O.G., Soroka O.V. 2017. Meteorological monitoring. In: Experience of organising monitoring studies of post-fire changes in steppe ecosystems: approaches and methods. Orenburg: South Ural. P. 40-44. [In Russian]

Langford G.J., Borden J.A., Major C.S., Nelson D.H. 2007. Effects of Prescribed Fire on the Herpetofauna of a Southern Mississippi Pine Savanna. Herpetologial Conservation and Biology 2(2): 153-143.

Lebedinskii A.A. 2017. On the issue of the role of state nature reserves in studying the effects of natural disasters on the example of the herpetofauna of the Kerzhensky State Nature Reserve. In: Book of Abstracts of the All-Russian Scientific Conference «Scientific Studies in Protected Areas». Simferopol: IT «ARIAL». P. 31. [In Russian]

Lebedinskii A.A., Pestov M.V. 2017. Features of post-wildfire recovery of forest herpetocomplexes as a consequence of physical and geographical peculiarities of the territory (on an example of the Kerzhensky Nature Reserve). Current Studies in Herpetology 17(1-2): 44-50. DOI 10.18500/1814-6090-2017-17-1-2-44-50 [In Russian]

Russell K.R., Van Lear D.H., Guynn D.C. 1999. Prescribed Fire Effects on Herpetofauna: Review and Management Implications. Wildlife Society Bulletin 27(2): 374-384.

Selyunina Z.V. 2008. The action of the pyrogenic factor on the fauna of terrestrial vertebrates in the Black Sea Biosphere Reserve region. In: Pryrodnychyi Almanakh, Prirodnicij almanah. Seria: Biologicni nauki 12: 83-90. [In Ukrainian]

Smith A.L., Muelders B., Bull C.M., Driscoll D.A. 2012. Wildfire-induced mortality of Australian reptiles. Herpetology Notes 5: 233-235.

Timoshenkov V.A., Timoshenkova V.V. 2007. Fires in the Khomutovskaya steppe: causes, information, consequences. Steppe Bulletin 23-24: 27-30. [In Russian]

\title{
ДИНАМИКА ЧИСЛЕННОСТИ И ВОЗРАСТНОГО СОСТАВА LACERTA AGILIS (REPTILIA, LACERTIDAE) ПОСЛЕ ПОЖАРОВ В ГОСУДАРСТВЕННОМ ПРИРОДНОМ ЗАПОВЕДНИКЕ «ОРЕНБУРГСКИЙ» (РОССИЯ)
}

\author{
А. Г. Бакиев", Р. А. Горелов, А. А. Кленина \\ Институт экологии Волжсккого бассейна РАН, Россия \\ *e-mail: herpetology@list.ru
}

\begin{abstract}
Изучались численность и половозрастная структура прыткой ящерицы (Lacerta agilis) в разные месяцы сезона активности 2015-2017 гг. на двух трансектах. Параллельные трансекты заложены в юго-восточной части участка «Буртинская степь» Оренбургского государственного заповедника (Россия). Длина каждого маршрута была равна 3 км. Ширина минерализованной полосы, разделяющей маршруты, была равна 9-11 м. Трансекта 2 была расположена на территории, которая сгорела в августе 2014 г. Трансекта 1 располагалась на территории, которая сгорела в августе 2016 г. По размеру и внешним морфологическим признакам особи прыткой ящерицы были разделены на три группы: молодые особи, взрослые самцы и взрослые самки. После измерений меченые животные возвращались в места отлова. Численность и половозрастная структура восстанавливались на маршрутах в мае - июне после первой зимовки, следующей за пожаром. Например, на трансекте 1 в конце апреля - начале мая 2015 г. встречаемость была почти в три раза выше (18.67 экз./км), чем на маршруте 2 (6.67 экз./км). Но в конце мая 2015 г. численность на обоих трансектах стала практически одинаковой (12.67 экз./км на трансекте 1 и 11.33 экз./км на трансекте 2). Молодые особи страдали от пожаров больше, чем взрослые. Так, после пожара 2016 г. доля ювенильных особей в середине мая 2017 г. составила 21.2\% от общего числа особей прыткой ящерицы, встреченных на сгоревшей трансекте 1, и 67.3\% на трансекте 2, сгоревшей в 2014 г. На наш взгляд, быстрое восстановление численности и половой возрастной структуры в Буртинской степи связано с миграцией особей прыткой ящерицы через минерализованную полосу, разделяющую горевшие и негоревшие трансекты.
\end{abstract}

Ключевые слова: заповедный участок «Буртинская степь», Оренбургская область, пожары, прыткая ящерица 